\title{
TRANSAKSI KEUANGAN YANG TIDAK WAJAR BERDASARKAN UNDANG- UNDANG NOMOR 8 TAHUN 2010 TENTANG PENCEGAHAN DAN PEMBERANTASAN TINDAK PIDANA PENCUCIAN UANG
}

\author{
Dhevi Nayasari Sastradinata, SH, MM
}

\begin{abstract}
Abstrak
Republik Indonesia sebagai negara hukum menghendaki terwujudnya sistem hukum nasional yang mantap dan mengabdi kepada kepentingan nasional yang bersumber hukum pada Pancasila dan Undang-Undang Dasar 1945.banyak tugas yang berkaitan dengan institusi lain menyebabkan OJK harus berkoordinasi dengan baik supaya tidak terjadi tumpang tindih kewenangan. Adapun koordinasi OJK dengan pihak lain yaitu Bank Indonesia, lembaga penjamin simpanan dan kementrian keuangan.

Berdasarkan latar belakang di atas, maka penulis mengetengahkan 2 (dua) perumusan masalah.Pertama mengenai bagaimana pengaturan mengenai transaksi keuangan di Indonesia yang tidak wajar berdasarkan Undang-Undang Nomor 8 Tahun 2010 tentang Pencegahan dan Pemberantasan Tindak Pidana Pencucian Uang.Kedua mengenai akibat hukum mengenai Transaksi tidak wajar tersebut.

Tipe penelitian yang dipakai oleh penulis adalah yuridis normatif.Metode penelitian yuridis normatif adalah suatu prosedur penelitian ilmiah untuk menemukan kebenaran berdasarkan logika keilmuan hukum dari sisi normatifnya.

Berdasarkan hasil pembahasan pada bab-bab sebelumnya, maka dapat diambil kesimpulan yang pertama:pengaturan dan pengawasan bank diarahkan untuk mengoptimalkan fungsi perbankan Indonesia agar tercipta sistem perbankan yang sehat secara menyeluruh maupun individual, dan mampu memelihara kepentingan masyarakat dengan baik, berkembang secara wajar dan bermanfaat bagi perekonomian nasional. Yang kedua adanya transaksi terhadap pengaturan dan pengawasan transaksi keuangan di Indonesia berakibat adanya kepastian hukum bagi pihak-pihak yang melanggar.sanksisanksi tersebut diharapkan dapat member efek jera. Dari kesimpulan diatas beberapa saran yang dapat di sampaikan diantaranya yang pertama adanya kerjasama dan koordinasi lintas institusi yang lebih baik ke depanya, baik Bank Indonesia, Otoritas Jasa Keuangan dan Pusat Pelaporan dan Analisis Transaksi Keuangan diharapkan dapat mengungkap transaksi keuangan yang tidak wajar di Indonesia, utamanya yang merugikan negara. Dan yang kedua pemantauan peraturan dan sanksi berlaku tetap harus dilakukan demi menjawab tantangan perkembangan dari waktu ke waktu.
\end{abstract}

\section{Kata Kunci : Transaksi Keuangan}

\section{A. Pendahuluan}

Transaksi adalah seluruh kegiatan yang menimbulkan hak dan/atau kewajiban atau menyebabkan timbulnya hubungan hukum antara dua pihak atau lebih. Transaksi Keuangan adalah Transaksi untuk melakukan atau menerima penempatan, penyetoran, penarikan, pemindahbukuan, pentransferan, pembayaran, hibah, sumbangan, penitipan, dan/atau penukaran atas sejumlah uang atau tindakan dan/atau kegiatan lain yang berhubungan dengan uang.

Seperti telah dijelaskan sebelumnya bahwa sebagai lembaga keuangan, kegiatan bank sehari-hari tidak akan terlepas dari bidang keuangan. Sama 
seperti halnya pedagang atau perusahaan lainya, kegiatan pihak perbankan secara sederhana dapat kita katakan adalah membeli uang (menghimpun dana) dan menjual uang (menyalurkan dana) kepada masyarakat umum.

Dalam melaksanakan kegiatan bank dibedakan antara kegiatan bank umum dengan kegiatan bank perkreditan rakyat.Kegiatan bank umum lebih luas dari bank perkreditan rakyat.Artinya produk ditawarkan oleh bank umum lebih beragam, hal ini disebabkan bank umum mempunyai kebebasan untuk menentukan produk dan jasanya.Sedangkan Bank Perkreditan Rakyat mempunyai keterbatasan tertentu sehingga kegiatannya lebih sempit. Adapun kegiatan-kegiatan perbankan yang ada di Indonesia dewasa ini adalah sebagai berikut:

\section{Kegiatan-kegiatan bank umum}

Menghimpun dana dari masyarakat (funding) dalam bentuk:

Simpanan Giro (Demand Deposit)

Simpanan Tabungan (Saving Deposit)

Simpanan Deposito (Time Deposit)

Menyalurkan dana ke masyarakat

(Lending) dalam bentuk :

Kredit Investasi

Kredit Modal Kerja

Kredit Perdagangan

Memberikan jasa-jasa bank lainnya

(services)seperti :

Transfer (Kirim Uang)

Inkaso (Collection)

Kliring (Clearing)

Save Deposit Box

Bank Card

Bank Notes (Valas)

Bank Garansi

Referensi Bank

Bank Daft

Letter of Credit $(L / C)$

Cek Wisata (Travellers Cheque)

Jual beli surat-surat berharga

Menerima setoran-setoran seperti :

Pembayaran pajak

Pembayaran air

Pembayaran telpon

Pembayaran listrik

Pembayaran kuliah
Melayani pembayaran-pembayaran seperti:

Gaji/Pensiun/honorarium

Pembayaran deviden

Pembayaran kupon

Pembayaran bonus/hadiah

Di dalam model perbankan dapat member atau menjadi:

Penjamin emisi (underwriter)

Penjamin (guarantor)

Wali amanat (trustee)

Perantara perdagangan efek

(pialang/broker)

Pedagang efek (dealer $)^{l}$

Perusahaan pengelola dana (investment company).

Tindak pidana perbankan dan tidak pidana di bidang perbankan merupakan

Tindak Pidana Ekonomi. Unsur-unsur

Tindak Pidana Ekonomi menurut

Conklin, yaitu:

Suatu perbuatan melawan hukum yang diancam dengan sanki pidana

Dilakukan oleh perorangan atau korporasi di dalam pekerjaanya yang sah atau dalam usahanya di bidang industri atau perdagangan

Tujuan memperoleh uang, kekayaan, menghindari pembayaran uang/menghindari

kekayaan/kerugian/keuntungan bisnis atau keuntungan pribadi.

Bentuk-bentuk pelanggaran ekonomi, antara lain:

Pelanggaran/penghindaran pajak;

Penipuan/kecurangan di bidang perkreditan (credit fraud);

Penggelapan dana masyarakat,penyalagunaan dana masyarakat;

Pelanggaran terhadap aturan keuangan;

Spekulasi dan penipuan transaksi tanah;

Delik-delik lingkungn;

Menaikan penyamaran atau sifat tersembunyi maksud dan tujuan kejahatanya;

Keyakinan si pelaku terhadap kebodohan, dan kesembronoan si

${ }^{1}$ Kasmir.Bank dan Lembaga Keuangan Lainnya.PT Rajagrafindo Persada. Jakarta.2014. halaman 38-40 
korban, kurang ahli, kurang pengetahuan, keteledoran korban;

Penyembunyian pelanggaran;

Melebihkan harga faktur;

Eksploitasi tenaga kerja;

Penipuan konsumen.

Tidak pidana di bidang perbankan merupakan White Collar Crime. White Collar Crime dapat dikelompokkan dalam:

Kejahatan yang dilakukan oleh kalangan profesi dalam melakukan pekerjaan, seperti advokat, akuntan, dokter;

Kejahatan yang dilakukan oleh pemerintah atau aparat, seperti korupsi, penyalagunaan kekuasaan, pelanggaran hak warga negara.

Tipologi kejahatan perbankan; penipuan/kecurangan di bidang perkreditan (credit fraud):

Penggelapan dana masyarakat (embezzlement of public fraud);

Penyelewengan/penyalagunaan dana masyarakat (misappropriation of public funds);

Pelanggaran terhadap peraturanperaturan keuangan (violation of currency regulation);

Pencucian uang (money laundering).

Pengenaan pidana terhadap kejahatan dan pelanggaran perbankan; umumnya mengacu ke Pasal 10 KUHP:

Pidana pokok dan pidana tambahan (penjara, kurung, denda, pencabutan hak-hak tertentu, perampasan barangbarang tertentu, pengumuman putusan hakim);

Sanksi Administratif oleh Bank Indonesia:Denda,teguran,penurunan tingkat kesehatan, larangan ikut kliring,pembekuan kegiatan usaha,pencabutan izin usaha (sanksi administratif tidak mengurangi ketentuan ancaman pidana).

Kemajuan teknologi dan globalisasi keuangan menyebabkan transaksi dalam negeri dan antarnegara dimungkinkan berlangsung hanya dalam beberapa detik. Di Indonesia hal ini juga sudah dapat dilakukan dengan adanya Automatic Teller Machine (ATM) dan Electronik Wire Transf. sementara itu perkrmbangan globalisasi ekonomi sekarang ini menyebabkan terbukanya ekonomi negara-negara berkembang bagi arus dana dari dan ke negara-negara maju.

Kemajuan teknologi informasi dan globalisasi keuangan mengakibatkan makin mendunia perdagangan barang dan jasa serta arus financial.Kemajuan tidak selamanya tidak berdampak positif bagi masyarakat, tetapi terkadang justru menjadi sarana berkembangnya kejahatan terutama kejahatan kerah putih (White Collar Crime), kejahatan bisnis (Businnes Crime) atau kejahatan korporasi (Coorporate Crime).

Keadaan tersebut di atas dipergunakan oleh orang-orang yang ingin mendapatkan keuntungan dari perbuatan yang tidak halal, yaitu menyelamatkan uang yang diperolehnya dari, missal perdagangan narkotika, hasil korupsi, insider training, dalam jual beli saham, penyelundupan senjata, pemalsuan kartu kredit, dan sebagainya. Di Amerika Serikat umpamanya diperkirakan \$ 100 milyar sampai dengan \$ 300 milyar dihasilkan dari perdagangan narkotika, dan $50 \%$ sampai dengan $70 \%$ dari jumlah tersebut diputihkan dan atau diinvestasikan kembali.

Menurut Remy Syahdaeni, sekalipun tidak dapat diketahui secara pasti berapa banyaknya uang yang dicuci setiap tahun melalui kegiatan Money Laundering, tetapi jumlah perkiraanya sangat besar. Mantan Managing Director IMF, Michel Candessus memperkirakan volume dari cross border money laundering antara 2$5 \%$ dari gross domestic product (GDP) dunia,bahkan menurutnya batas terbawah dari kisaran tersebut,yaitu jumlah yang dihasilkan dari kegiatan narcotics trafficking, arms trafficking, bank fraud, securities fraud, counterfeiting dan kejahatan yang sejenis itu yang dicuci di seluruh dunia 
setiap mencapai jumlah hampir US \$ 600 Milyar. $^{2}$

Kegiatan pencucian uang ini tentu saja sangat merugikan masyarakat, menurut pemerintah kanada dalam satu paper, yang dikeluarkan oleh Departemen of Justice Canada, yang berjudul Electronic Money Laundering :An Environmental Scan yang diterbitkan Oktober 1998, dampak negatif yang ditimbulkan oleh kegiatan money laundering ini dapat berupa :

Para penjual dan pengedar narkoba, para penyelundup dan para penjahat lainya dapat memperluas operasinya, hal ini akan meningkatkan biaya penegakan hukum untuk memberantas dan biaya perawatan serta pengobatan kesehatan bagi para korban atau para pecandu narkoba.

Kegiatan money laundering mempunyai potensi untuk mengrongrong masyarakat keuangan (financial community) sebagai akibat demikian besar jumlahnya uang yang terlibat dalam kegiatan tersebut.Potensi untuk melakukan korupsi meningkatkan bersamaan dengan peredaran jumlah uang haram yang sangat besar.

Money laundering mengurangipendapatan pemerintah dari pajak dan secara tidak langsung merugikan para pembayar pajak yang jujur dan mengurangi kesempatan kerja yang sah.

Mudahnya uang masuk ke kanada telah menarik unsur-unsur yang tidak diinginkan melalui perbuatan menurunkan tingkat kualitas hidup dan meningkatkan kekhawatiran terhadap keamanan nasional.

Dampak money laundering bagi negara kanada tersebut diatas, tampaknya tidak jauh berbeda dengan apa yang dialami oleh Indonesia dari praktik money laundering tersebut. Begitu besarnya kerugian yang ditimbulkan dari praktik pencucian uang, oleh karena itu upaya untuk mecegah tindak pidana

${ }^{2}$ Neny Sri Imaniyati.Pengantar Hukum Perbankan Indonesia.PT Refika Aditama. Bandung. 2010. halaman 173 pencucian uang telah dilakukan oleh berbagai negara.Perang terhadap kegiatan pencucian uang oleh organisasi-organisasi kejahatan dan oleh individu-individu yang tidak tergabung.

Sebelum diuraikan faktor-faktor pendorong pencucian uang,akan diuraikan terlebih dahulu tentang pengertian atau batasan pencucian uang (money laundering). UU No.15 tahun 2002 tidak memberikan pengertian tentang tidak pidana pencucian uang, tetapi penjelasan UU tersebut menggambarkan tindakan pencucian uang sebagai :"Upaya untuk menyembunyikan atau menyamarkan asal-usul harta kekayaan yang diperoleh dari tindak pidana sebagaimana dimaksud dalam undang-undang ini".

UU No. 15 Tahun 2002 tentang Tindak Pidana Pencucian Uang telah diamandemen dengan UU No. 25 Tahun 2003 tentang Perubahan Atas UU No. 15 Tahun 2002 tentang Tindak Pidana Pencucian Uang pun untuk selanjutnya disebut UU TPPU-tidak memberikan pengertian tentang tindak pidana pencucian uang,akan tetapi memberikan contoh tindak pidana yang dapat dikategorikan sebagai tindak pidana pencucian uang.

Hal ini tercantum dalam Pasal 1 ayat (1), yang merumuskan tentang pencucian uang sebagai: "Perbuatan menempatkan, mentransfer, membayarkan, membelanjakan, menghibahkan, menyumbangkan, menitipkan, membawa keluar negeri, menukarkan atau perbuatan lainnya atas harta kekayaan yang diketahuinya atau patut diduga merupakan hasil tindak pidana dengan maksud untuk menyembunyikan atau menyamarkan asal usul harta kekayaan sehingga seolah-olah menjadi harta kekayaan yang sah."

Black's Law Dictionary
memberikan penjelasan money
laundering sebagai :
"terms used to describe investment or
other transfer of money flowing from
recaketeering, drung transaction, and
other illegal sources into legitimate


channels so that its original source cannot be traced" (yang kurang lebih menjelaskan tentang istilah yang digunakan utuk menggambarkan investasi atau transfer lain dari uang yang mengalir dari sumber ilegal ke sumber legal sehingga sumber aslinya tidak dapat diketahui).

Pengertian yang lebih lengkap tentang pencucian uang dikemukakan oleh Remy Syahdaeni, yang memberikan batasan tentang pencucian uang sebagai berikut:

Rangkaian kegiatan yang merupakan proses yang dilakukan oleh seseorang atau organisasi terhadap uang haram,yaitu uang yang berasal dari kejahatan, dengan maksud untuk menyembunyikan atau menyamarkan asal usul uang tersebut dari pemerintah atau otoritas yang berwenang melakukan penindakan terhadap tindak pidana dengan cara terutama memasukan uang tersebut kedalam sistem keuangan (financial system), sehingga uang tersebut kemudian dapat dikeluarkan dari sistem keuangan itu sebagai uang halal. $^{3}$

Edi Setiadi menyatakan bahwa money laundering merupakan istilah hukum.Yang mempermasalahkan adalah legalitas dari sumber pendapatan atau kekayaan ilegal tersebut. Lebih lanjut, Edi Setiadi mengemukakan bahwa pemutihan uang dapat disebut sebagai suatu cara atau proses untuk mengubah uang haram yang sebenarnya dihasilkan dari sumber ilegal sehingga seolah-olah menjadi berasal dari sumber yang halal.

Dari beberapa pengertian dan contoh-contoh diatas,dapat dilihat dua tingkat kejahatan dalam kegiatan pencucian uang, yaitu:

kejahatan yang menghasilkan uang itu sendiri, missal perdagangan obat bius, korupsi, dan sebagainya.

Kejahatan pemutihan uang, yakni uang hasil kejahatan itu diproses pemutihanya di mana terhadap pemrosesan ini sungguhpun secara formal kelihatanya legal, tetapi secara material dianggap ilegal.

Adapun pengaturan tentang transaksi yang mencurigakan dalam Undang-Undang Nomor 8 Tahun 2010 adalah sebagai berikut :

(1) Penyedia jasa keuangan sebagaimana dimaksud dalam Pasal 17 ayat (1) huruf a wajib menyampaikan laporan kepada PPATK yang meliputi:

a. Transaksi Keuangan Mencurigakan;

b. Transaksi Keuangan Tunai dalam jumlah paling sedikit Rp500.000.000,00 (lima ratus juta rupiah atau dengan mata uang asing yang nilainya setara, yang dilakukan baik dalam satu kali Transaksi maupun beberapa kali Transaksi dalam 1 (satu) hari kerja; dan/atau

c. Transaksi Keuangan transfer dana dari dan ke luar negeri.

(2) Perubahan besarnya jumlah Transaksi Keuangan Tunai sebagaimana dimaksud pada ayat (1) huruf b ditetapkan dengan Keputusan Kepala PPATK.

(3) Besarnya jumlah Transaksi Keuangan transfer dana dari dan ke luar negeri yang wajib dilaporkan sebagaimana dimaksud pada ayat (1) huruf c diatur dengan Peraturan Kepala PPATK.

(4) Kewajiban pelaporan atas Transaksi Keuangan Tunai sebagaimana dimaksud pada ayat (1) huruf b dikecualikan terhadap:

a. Transaksi yang dilakukan oleh penyedia jasa keuangan dengan pemerintah dan bank sentral;

b. Transaksi untuk pembayaran gaji atau pensiun; dan

c. Transaksi lain yang ditetapkan oleh Kepala PPATK atau atas permintaan penyedia jasa keuangan yang disetujui oleh PPATK

(5) Kewajiban pelaporan sebagaimana dimaksud pada ayat (1) huruf b tidak berlaku untuk transaksi yang dikecualikan.

Pasal 24

(1) Penyedia jasa keuangan wajib membuat dan menyimpan daftar Transaksi yang dikecualikan

${ }^{3}$ ibid halaman $175-176$ 
sebagaimana dimaksud dalam Pasal 23 ayat (4).

(2) Penyedia jasa keuangan yang tidak membuat dan menyimpan daftar Transaksi yang dikecualikan sebagaimana dimaksud pada ayat (1) dikenai sanksi administratif.

Pasal 25

(1) Penyampaian laporan Transaksi Keuangan Mencurigakan sebagaimana dimaksud dalam Pasal 23 ayat (1) huruf a dilakukan sesegera mungkin paling lama 3 (tiga) hari kerja setelah penyedia jasa keuangan mengetahui adanya unsur Transaksi Keuangan mencurigakan.

(2) Penyampaian laporan Transaksi Keuangan Tunai sebagaimana dimaksud dalam Pasal 23 ayat (1) huruf b dilakukan paling lama 14 (empat belas) hari kerja terhitung sejak tanggal Transaksi dilakukan.

(3) Penyampaian laporan Transaksi Keuangan transfer dana dari dan ke luar negeri sebagaimana dimaksud dalam Pasal 23 ayat (1) huruf c dilakukan paling lama 14 (empat belas) hari kerja terhitung sejak tanggal Transaksi dilakukan.

(4) Penyedia jasa keuangan yang tidak menyampaikan laporan kepada PPATK sebagaimana dimaksud pada ayat (1), ayat (2), dan ayat (3), dikenai sanksi administratif.

(5) Ketentuan lebih lanjut mengenai bentuk, jenis, dan tata cara penyampaian laporan sebagaimana dimaksud pada ayat (1), ayat (2), dan ayat (3) diatur dengan Peraturan Kepala PPATK.

Menurut UU Nomor 7 Tahun 2011 Tentang Mata Uang, Pasal 1, mata uang yang dikeluarkan oleh Negara Kesatuan Republik Indonesia disebut rupiah.

Jika berbicara masalah uang, maka erat sekali dengan istilah bank.Bank dan uang telah menjadi satu kesatuan yang tidak dapat dipisahkan. Menurut Undang-Undang Nomor 10 Tahun 1998, bank adalah badan usaha yang menghimpun dana dari masyarakat dalam bentuk simpanan dan menyalurkannya kepada masyarakat dalam bentuk kredit dan/atau bentuk- bentuk lainnya dalam rangka meningkatkan taraf hidup orang banyak. Berdasarkan fungsinya, bank dapat diklasifikasikan menjadi :

Bank Umum

Bank yang melaksanakan kegiatan usaha secara konvensional dan/atau prinsip syariah.

Bank Perkreditan Rakyat (BPR)

Bank yang melaksanakan kegiatan usahanya secara konvensional atau berdasaarkan prinsip syariah yang dalam kegiatannya tidak memberikan jasa dalam lalu lintas pembayaran.

Berdasarkan kepemilikannya, bank dapat diklasifikasikan menjadi :

Bank pemerintah seperti Bank Negara Indonesia, Bank Rakyat Indonesia.

Bank Swasta Nasional, seperti Bank Permata.

Bank Koperasi, seperti Bank Bukopin.

Bank Asing, seperti Bank of Tokyo.

Bank Campuran, seperti Bank ANZ Indonesia.

Berdasarkan statusnya, bank dapat diklasifikan menjadi :

Bank Devisa, bank yang melaksanakan transaksi luar negeri.

Bank Non Devisa

Berdasarkan cara menentukkan harga, bank dapat diklasifikasikan menjadi :

Bank Konvensional

Bank Syariah

Di bank inilah, terjadi antara seseorang atau yang lebih dikenal dengan nasabah melakukan transaksi keuangan, Nasabah melakukan berbagai macam transaksi di bank. Adapun beberapa kegiatan dari bank adalah sebagai berikut :

Menghimpundana (funding)

Secara umum jenis simpanan yang diotawarkan di bank adalah giro, tabungan , simpanan, deposito dan sertifikat deposito.

Menyalurkan dana atau kredit (Lending) Memberikan jasa-jasa lain seperti pengiriman uang, kliring, inkaso, kotak penyimpanan, kartu kredit, bank notes, garansi bank, bank draft, Letter ofCredit (L/C), cek pelawat (Traveller Cheque), 
menerima setoran-setoran, melayani pembayaran-pembayaran. ${ }^{4}$

Dewasa ini, dapat diamati bahwa transaksi dalam perbankan tidak hanya fokus pada satu hal saja.Bahkan nasabah bank diberikan fasilitas dan kemudahan dalam bertransaksi.Pengawasan dalam dunia perbankan menjadi amat penting, terlebih dari kemudahan yang ditawarkan dapat menjadi celah untuk menyalahgunakan fasilitas dan kemudahan yang diberikan.Akhir-akhir ini dunia perbankan juga menjadi sasaran utama para koruptor untuk menyamarkan harta hasil korupsinya.Tidak hanya masalah pencucian uang, tetapi juga untuk pendanaan teroris.

Kejahatan pencucian uang adalah bebagai upaya untuk menempatkan, mentransfer,

membelanjakan,

menyumbangkan, membayarkan, menghibahkan, menitipkan, membawa keluar negeri, menukarkan, atau perbuatan lain atas harta kekayaan yang di ketahui atau diduga merupakan hasil tidak pidana dengan maksud untuk menyembunyikan, atau menyamarkan asal usul harta kekayaan sehingga seolah-olah menjadi harta kekayaan yang sah (pasal 1 ayat 1 UU No.25 tahun 2003). Sebagai bagian dari kejahatan kerah putih (white collar crimes), tindak kejahatan ini dapat di lakukan oleh individu maupun organisasi atau korporasi melalui tahapan placement, layering, dan integration.Oleh karena itulah dibentuk Otoritas Jasa Keuangan. ${ }^{5}$

Berdasarkan Undang-Undang Nomor 21 Tahun 2011, Otoritas Jasa Keuangan adalah lembaga yang independen dan bebas dari campur tangan pihak lain, yang mempunyai tugas, wewenang pengaturan, pengawasan, pemeriksaan dan penyidikan. Otoritas Jasa Keuangan

\footnotetext{
${ }^{4}$ Tri Hendro SP, Conny Tjandra Raharja. Bank dan Institusi Keuangan Non-Bank di Indonesia. UPP STIM YKPN. Yogyakarta. halaman 125-133

${ }^{5}$ Ibid halaman 476
}

melaksanakan tugas pengaturan dan pengawasan terhadap :

Kegiatan jasa keuangan di sektor perbankan

Kegiatan jasa keuangan di sektor pasar modal

Kegiatan jasa keuangan pada sektor perasuransian dana pension, lembaga pembiayaan dan lembaga jasa keuangan lainnya.

Untuk melaksanakan tugas pengaturan, Otoritas Jasa Keuangan (OJK) mempunyai wewenang :

Menetapkan peraturan pelaksanaan UU, Menetapkan peraturan perundangundangan di sektor jasa keuangan.

Menetapkan peraturan dan keputusan OJK

Menetapkan peraturan mengenai pengawasan di sektor jasa keuangan

Menetapkan kebijakan mengenai pelaksanaan tugas OJK.

Menetapkan paraturan mengenai tata cara penetapan perintah tertulis terhadap Lembaga Jasa Keuangan (LJK) dan pihak tertentu.

Menetapkan peraturan mengenai tata cara penetapan pengelola statur LJK.

Menetapkan struktur organisasi dan infrastruktur, serta mengelola, memelihara dan menatausahakan kekayaan dan kewajiban.

Menetapkan peraturan mengenai tata cara pengenaan sanksi dengan ketentuan peraturan perundang-undang di sektor.jasa keuangan.

Dalam melaksanakan tugas pengawasan, OJK berwenang untuk :

Menetapkan kebijakan operasional pengawasan terhadap kegiatan jasa keuangan.

Mengawasi pelaksanaan tugas pengawasan yang dilaksanakan kepala eksekutik.

Melakukan pengawasan, pemeriksaan, penyidikan, perlindunga konsumen, dan tindakan lain terhadap LJK, pelaku, dan/atau penunjang kegiatan jasa keuangan.

Memberikan perintah tertulis kepada LJK dan/atau pihak tertentu.

Melakukan penunjukan atas pengelola statuter. 
Menetapkan penggunaan pengelola statuter.

Menetapkan sanksi administratif terhadap pihak yang melakukan pelanggaran terhadap peraturan perundang-undangan di sektor jasa keuangan.

Memberikan atau mencabut: (a) izin usaha; (b) izin perorangan: (c) efektifnya pernyataan pendaftaran; (d) SuratTanda Terdaftar (STT); (e) persetujuan untuk melakukan kegiatan usaha; (f) pengesahan; (g) persetujuan atas penetapan pembubaran, dan (h) penetapan lain sesuai peraturan perundang-undangan di sektor jasa keuangan. ${ }^{6}$

Untuk menjalankan kegiatannya, OJK memiliki benerapa asa penting meliputi : Asas independensi : OJK bersifat independen dalam melaksanakan kegiatannya.

Asas kepastian hukum : OJK mengutamakan landasan dari UU yang berlaku untuk melakukan kegiatannya.

Asas kepentingan umum: semua kegiatan OJK didasarkan untuk melindungi dan memajukan kepentingan umum.

Asas profesionalitas.

Asas integritas: OJK selalu berpegang teguh pada nilai moral dalam setiap tindakan dan keputusan yang diambilnya.

Asas keterbukaan.

Asas akuntabilitas: seluruh kegiatan OJK dapat dipertanggungjawabkan kepada publik. $^{7}$

\section{B. Metode Penelitian}

Tipe penelitian hukum yang digunakan adalah yuridis normatif. Metode penelitian yuridis normatif adalah suatu prosedur penelitian ilmiah untuk menemukan kebenaran berdasarkan logika keilmuan hukum dari sisi normatifnya. ${ }^{8}$

\footnotetext{
${ }^{6}$ Ibid halaman $490-491$

${ }^{7}$ Ibid halaman. 490

${ }^{8}$ Johnny Ibrahim, Teori \& Metodologi

Penelitian Hukum Normatif, Banyumedia
}

Oleh karena itu penelitian hukum ini difokuskan untuk mengkaji kewenangan Otoritas Jasa Keuangan sebagai salah satu institusi yang memilik kewenangan untuk mengawasi sektor jasa keuangan yang pembentukannya diatur dalam Undang-Undang Nomor 21 Tahun 2011 tentang Otoritas Jasa Keuangan, selain Undang-Undang Nomor 10 Tahun 1998 tentang Perubahan Atas UndangUndang Nomor 8 Tahun 2010 tentang pencegahan dan pemberantasan tindak pidana pencucian uang

\section{Hasil Dan Pembahasan}

Dalam pembicaraan sehari-hari,bank di kenal sebagai lembaga keuangan yang kegiatan utamanyamenerima simpanan giro, tabungan dan deposito. Kemudian bank juga dikenal sebagai tempat untuk meminjam uang (kredit) bagi masyarakat yang membutuhkan.di samping itu,bank juga dikenal sebagai tempat untuk menukar uang,memindahkan uang atau menerima segala macam bentuk pembayaran dan setoran seperti pembayaran listrik, telpon, air, pajak, uang kuliah, dan pembayaran lainya.

Dalam pasal 1 UndangUndang Nomor 7 Tahun 2011 tentang Mata Uang sebagai berikut:

Ciri rupiah adalah tanda tertentu pada setiap rupiah yang ditetapkan dengan tujuan untuk menunjukkan identitas, membedakan harga atau nilai nominal dan mengamankan rupiah tersebut dari upaya pemalsuan.

Kertas uang adalah bahan baku yang digunakan untuk membuat rupiah kertas yang mengandung unsur pengaman dan yang tahan lama.

Logam uang adalah bahan baku yang digunakan untuk membuat rupiah logam yang mengandung unsur pengaman dan yang tahan lama.

Rupiah tiruan adalah suatu benda yang bahan, ukuran, warna, gambar, dan atau desainnya menyerupai rupiah yang

Publishing, Cetakan Keenam, Malang, 2012, halaman 57 
dibuat, dibentuk, dicetak, digandakan, atau diedarkan, tidak digunakan sebagai alat pembayaran dengan merendahkan kehormatan rupiah sebagai simbol negara.

Rupiah palsu adalah suatu benda yang bahan, ukuran, warna, gambar, dan/atau desainnya menyerupai rupiah yang dibuat,dibentuk, dicetak, digandakan, diedarkan, atau digunakan sebagai alat pembayaran secara melawan hukum.

Pengelolaan rupiah adalah kegiatan yang mencakup perencanaan, pencetakan, pengeluaran, pengedaran, pencabutan, dan penarikan serta pemusnahan rupiah yang dilakukan secara efektif, efisien, transparan dan akuntabel.

Pasal 21 dan 23 mengatur penggunaan rupiah sebagai berikut:

Pasal 21

Rupiah wajib digunakan dalam:

Setiap transaksi yang mempunyai tujuan pembayaran.

Penyelesaian kewajiban lainnya yang harus dip[enuhi dengan uang.

Transaksi keuangan lainnya yang dilakukan di Wilayah Negara Kesatuan Republik Indonesia.

Kewajiban sebagaimana dimaksud pada ayat (1) tidak berlaku lagi:

Transaksi tertentu dalam rangka pelaksanaan anggaran dan pendapatan dan belanja negara.

Penerimaan atau pemberian hibah dari atau ke luar negeri.

Transaksi perdagangan internasional.

Simpanan di bank dalam valuta asing.

Transaksi pembiayaan internasional

Pasal 23

Setiap orang dilarang menolak untuk menerima rupiah yang penyerahannya dimaksudkan sebagai pembayaran atau untuk menyelesaikan kewajiban yang harus dipenuhi dengan rupiah dan/atau untuk transaksi keuangan lainnya di Wilayah Negara Kesatuan Republik Indonesia, kecuali karena terdapat keraguan atas keaslian rupiah.

Ketentuan sebagaimana dimaksud pada ayat (1) dikecualikan untuk penyelesaian kewajiban dalam valuta asing yang telah diperjanjikan secara tertulis. ${ }^{9}$

Dalam Undang-Undang Dasar 1945 juga dijelaskan pada Pasal 23 B yang berbunyi :"Macam dan harga mata uang ditetapkan dengan undang-undang.". Fungsi-fungsi dari uang secara umum yang ada dewasa ini adalah sebagai berikut.

Alat tukar menukar

Dalam hal ini uang digunakan sebagai alat untuk membeli atau menjual suatu barang maupun jasa. Dengan kata lain, uang dapat dilakukan untuk membayar terhadap barang yang akan dibeli atau diterima sebagai akibat dari penjualan barang dan jasa.

Satuan hitung

Fungsi uang sebagai satuan hitung menunjukkan nilai dari barang dan jasa yang dijual atau dibeli.Besar kecilnya nilai yang dijadikan sebagai satuan hitung dalam menetukan harga barangdan jasa secara mudah.

Penimbun kekayaan

Dengan menyimpan uang berarti kita menyimpan atau menimbun kekayaan sejumlah uang yang disimpan, karena nilai uang tersebut tidak akan berubah. Uang yang disimpan menjadi kekayaan dapat berupa uang tunai atau uang yang disimpan di bank dalam bentuk rekening.

Standar pencicilan utang

Dengan adanya uang akan mempermudah menentukan standar pencicilan utang piutang secara tepat dan cepat, baik secara tunai maupun secara angsuran.

Adapun jenis-jenis uang yang dapat dilihat dari berbagai sisi adalah sebagai berikut.

Berdasarkan bahan

Uang logam, merupakan uang dalam bentuk koin yang terbuat dari logam, baik dari aluminium, kupronikel, bronze, emas, perak atau perunggu dan bahan lainnya.

\footnotetext{
${ }^{9}$ Tri Hendro SP. Conny Tjandra Rahardja. Bank \& Institusi Keuangan Non Bank di Indonesia. UPP STIM YKPN.

Yogyakarta.2014. halaman 2-3
} 
Uang kertas, merupakan uang yang bahannya terbuat dari kertas atau bahan lainnya.

Berdasarkan nilai

Bernilai penuh (full body money), merupakan uang yang nilai intrinsiknya sama dengan nilai nominalnya. Sebagai contoh uang logam, dimana nilai bahan yang membuat uang tersebut sama dengan nominal yang tertulis di uang.

Tidak bernilai penuh (representatif full bodied money), merupakan uang yang nilai intrinsiknya lebih kecil dari nilai nominalnya.

\section{Berdasarkan lembaga}

Uang kartal, merupakan uang yang diterbitkan oleh Bank Sentral baik uang logam maupun uang kertas.

Uang giral, merupakan uang yang diterbitkan oleh Bank Umum seperti cek, bilyet giro, traveler cheque, dan credit card.

Berdasarkan kawasan

Uang Lokal, merupakan uang yang berlaku di suatu negara tertentu.

Uang Regional, merupakan uang yang berlaku di kawasan tertentu yang lebih luas dari uang lokal seperti untuk kawasan benua Eropa berlaku mata uang tunggal Eropa yaitu Euro.

Uang Internasional, merupakan uang yang berlaku antar negara seperi US Dollar dan menjadi standart pembayaran internasional. ${ }^{10}$

Menurut undang-undang RI Nomor 10 Tahun 1998 tentang Perbankan, yang dimaksud dengan BANK adalah "badan usaha yang menghimpun dana dari masyarakat dalam bentuk simpanan dan menyalurkan kepada masyarakat dalam bentuk kredit dan atau bentuk-bentuk lainya dalam rangka meningkatkan taraf hidup rakyat banyak."

Dari pengertian di atas dapat dijelaskan secara lebih luas lagi bahwa bank merupakan perusahaan yang bergerah dalam bidang keuangan, artinya

\footnotetext{
${ }^{10}$ Kasmir.Bank dan Lembaga Keuangan Lainnya.PT. Raja Grafindo Persada. Jakarta.2014. halaman 17-20
}

aktivitas perbankan selalu berkaitan dalam bidang keuangan. Sehingga berbicara mengenai bank Aktifitas perbankan yang pertama adalah menghimpun dana dari masyarakat luas yang di kenal dengan istilah di dunia perbankan adalah funding. Pengertian menghimpun dana maksudnya adalah mengumpulkan atau mencari dana dengan cara membeli dari masyarakat luas.

Pembelian dana dari masyarakat ini dilakukan oleh bank dengan cara memasang berbagai strategi agar masyarakat mau menanamkan dananya dalam bentuk simpanan. Jenis simpanan yang dapat di pilih oleh masyarakat adalah seperti giro, tabungan, sertifikat deposito, dan deposito berjangka.

Agar masyarakat mau menyimpan uangnya di bank, maka pihak perbankan memberikan rangsangan berupa balas jasa yang akan di berikan kepada si penyimpan. Balas jasa tersebut dapat berupa bunga, bagi hadiah, bagi hasil, pelayanan atau balas jasa yang lain. Semakin tinggi balas jasa yang diberikan, akan menambah minat masyarakat untuk menyimpan uangnya. Oleh karena itu, pihak perbankan harus memberikan berbagai rangsangan dan kepercayaan sehingga masyarakat berminat untuk menanamkan dananya.

Setelah memperoleh dana dalam bentuk simpanan dari masyarakat, maka oleh perbankan dana tersebut di putarkan kembali atau dijualkan kembali ke masyarakat dalam bentuk pinjaman atau lebih dikenal dengan istilah kredit (lending). Dalam pemberian kredit juga di kenakan jasa pinjaman kepada penerima kredit (debitur) dalam bentuk bunga dan biaya administrasi.Sedangkan bagi bank yang berdasarkan prinsip syariah dapat berdasarkan bagi hasil atau penyertaan modal.

Besarnya bunga kredit yang sangat dipengaruhi oleh besarnya bunga simpanan.Semakin besar atau semakin mahal bunga simpanan, maka semakin besar pula bunga pinjaman dan demikian pula sebaliknya. Di samping bunga simpanan pengaruh besar kecil 
bunga pinjaman juga dipengaruhi oleh keuntungan yang diambil, biaya operasi yang di keluarkan, cadangan risiko kredit macet, pajak serta pengaruh lainya. Jadi dapat disimpulkan bahwa kegiatan menghimpun dana (funding) dan menyalurkan dana (lending) ini merupakan kegiatan utama perbankan.

Keuntungan utama dari bisnis perbankan yang berdasarkan prinsip konvensional diperoleh dari selisih bunga simpanan yang diberikan kepada penyimpan dengan bunga pinjaman atau kredit yang di salurkan. Keuntungan dari selisih bunga ini di bank dikenal dengan istilah spread based. Apabila suatu bank mengalami suatu kerugian dari selisih bunga, di mana suku bunga simpanan lebih besar dari suku bunga kredit, maka istilah ini dikenal dengan nama negative spread. ${ }^{11}$

\section{Asal Mula Kegiatan Perbankan}

Sejarah mencatat asal mula dikenalnya kegiatan perbankan adalah pada zaman kerjaan tempo dulu di daratan eropa. Kemudian usaha perbankan ini berkembang ke asia afrika oleh para pedagang. Perkembangan perbankan di Asia, Afrika dan Amerika di bawah oleh bangsa Eropa pada saat melakukan penjajahan ke negara jajahanya baik di Asia, Afrika maupun benua Amerika.

Jika kita telusuri sejarah dikenalnya kegiatan perbankan dimulai dari jasa penukaran uang.Sehingga dalam sejarah perbankan, arti bank dikenal sebagai meja tempat menukarkan uang. Dalam perjalanan sejarah kerajaan tempo dulu mungkin penukaran uangnya dilakukan antarkerajaan yang satu dengan kerajaan yang lain. Kegiatan penikaran uang ini sekarang dikenal nama dengan pedagang valuta asing (money change) .

$\begin{array}{lrr}\text { Kemudian dalam perkembangan } & \text { pemiatan } & \text { operasional } \\ \text { selanjutnya } & \text { kegiatan } \\ \text { perbankan berkembang lagi } & \text { menjadi } \\ \text { tempat penitipan uang atau yang disebut } \\ \text { sekarang ini } & \text { kegiatan } \\ \text { simpanan.Berikutnya } & \text { kegiatan } \\ \text { perbankan bertambah dengan } & \text { kegiatan }\end{array}$

${ }^{11}$ Ibid halaman 24-25 peminjaman uang.Uang yang di simpan oleh masyarakat oleh perbankan di pinjamkan kembali ke masyarakat yang membutuhkanya.

Jasa-jasa bank lainya menyusul sesuai dengan perkembangan zaman dan kebutuhan masyarakat yang semakin beragam.Akibat dari kebutuhan masyarakat atas jasa keuangan semakin meningkat dan beragam, maka peranan dunia perbankan semakin di butuhkan oleh seluruh lapisan masyarakat baik yang berada di negara maju maupun negara berkembang.Bahkan dewasa ini perkembangan dunia perbankan semakin pesat dan modern, perbankan semakin mendominasi perkembangan ekonomi dan bisnis suatu negara.Bahkan aktivitas dan keberadaan perbankan sangat menentukan kemajuan suatu negara.

\section{Sejarah Perbankan}

Usaha perbankan itu sendiri baru di mulai pada zaman Babylonia kemudian dilanjutkan ke zaman Yunani Kuno dan Romawi. Namun,pada saat itu tugas utama bank hanyalah tempat tukar menukar uang.

Seiring dengan perkembangan perdagangan dunia, perkembangan perbankan pun semakin pesat karena perkembangan dunia perbankan tidak terlepas dari perkembangan perdagangan.Perkembangan perdangan semula hanya di daratan Eropa akhirnya menyebar ke Asia Barat.Bank-bank yang sudah terkenal pada saat itu di benua Eropa adalah Bank Venesia tahun 1171, kemudian menyusul bank of Genoa dan Bank Venesia tahun 1320.Sebaliknya perkembangan perbankan di daratan inggris baru di mulai pada abad ke-16. Namun karena Inggris yang begitu aktif mencari daerah perdagangan yang kemudian dijajah,maka perkembangan perbankan pun ikut dibawah ke negara jajahannya. Sejarah perbankan di Indonesia tidak terlepas dari zaman penjajahan Hindia Belanda.Pada saat itu terdapat beberapa bank yang memegang peran penting di 
Hindia Belanda. Bank-bank yang ada, yaitu antara lain :

De Javasche NV

De Post Paar Bank

De Algemenevolks Crediet Bank

Nederland Handles Maatscappij (NHM)

Nationale Handles Bank (NHB)

De Escompto Bank NV.

Disamping itu, terdapat pula Bank-bank milik pribumi, China, Jepang dan Eropa lainya. Bank-bank tersebut antara lain :

Bank Nasional Indonesia

Bank Abuan Saudagar

NV Bank Boemi

The Charteredbank of India

The Yokoyama Species Bank

The Matsui Bank

The Bank of China

Batavia Bank

Di zaman kemerdekaan perbankan di Indonesia bertambah maju dan berkembang lagi.Beberapa Bank Belanda dinasionalisasi oleh Pemerintah Indonesia. Bank-bank yang ada di zaman awal kemerdekaan antara lain:

Bank Negara Indonesia yang berdiri tanggal 5 Juli 1946 kemudian menjadi BNI 1946

Bank Rakyat Indonesia yang berdiri tanggal 22 Februari 1946. Bank ini berasal dari DE ALGEMENEVOLKS CREDIET Bank atau Syomin Ginko

Bank Surakarta MAI (Maskapai Adil Makmur)tahun 1945 di Solo

Bank Indonesia di Palembang tahun 1946

Bank Dagang Nasional Indonesia tahun 1946 di Medan

Indonesia Banking Corporation tahun 1947 di Yogyakarta, kemudian menjadi Bank Amerta

NV Bank Sulawesi di Manado tahun 1946

Bank Dagang Indonesia NV di Banjarmasin tahun 1949

Kalimantan Corporation Trading di Samarinda tahun 1950 kemudian merger dengan Bank Pasifik

Bank Timur NV di Semarang berganti nama menjadi Bank Gemari, kemudian merger dengan Bank Central Asia (BCA) tahun 1949

Sejarah Bank Pemerintah
Seperti diketahui bahwa bangsa Indonesia mengenal dunia perbankan dari bekas penjajahnya, yaitu Belanda.Oleh karena itu, sejarah perbankan pun tidak lepas dari pengaruh negara yang menjajahnya, baik untuk Bank Pemerintah maupun bank swasta nasional. Berikut ini akan dijelaskan secara singkat sejarah Bank-bank milik pemerintah, yaitu sebagai berikut.

Bank Sentral

Bank sentral di Indonesia adalah Bank Indonesia (BI) berdasarkan UU No.13 Tahun 1968.Kemudian ditegaskan lagi oleh Undang-Undang Nomor 23 Tahun 1999.Bank ini sebelumnya berasal dari De Javasche Bank yang dinasionalisasi tahun 1951.

Bank Rakyat Indonesia dan Bank Ekspor Impor

Bank ini berasal dari De Algemene Volkcrediet Bank, kemudian dilebur menjadi Bank Tunggal dengan nama Bank Nasional Indonesia (BNI) Unit II yang bergerak di bidang rural dan eksim dipisahkan lagi menjadi:

Yang membidangi rural menjadi Bank Rakyat Indonesia (BRI) dengan UU No.21 Tahun 1968

Yang membidangi exim dengan UU No.22 Tahun 1968 menjadi Bank Expor Impor Indonesia

Bank Negara Indonesia 1946 (BNI)

Bank ini menjalankan fungsi BNI unit III dengan UU Nomor 17 Tahun 1968 berubah menjadi Bank Negara Indonesia 1946

Bank Dagang Negara (BDN)

BDN berasal dari Escompto Bank yang dinasionalisasi dengan PP Nomor 13 Tahun 1960, namun PP ini dicabut dan diganti dengan UU No.18 Tahun 1968 menjadi Bank Dagang Negara. BDN satu-satunya bank pemerintah yang berada di luar Bank Negara Indonesia Unit.

Bank Bumi Daya (BBD)

BBD semula berasal dari Nederlandsch Indischeb Handles Bank kemudian menjadi Nationale Handlesbank, selanjutnya bank ini menjadi Bank Negara Indonesia Unit IV dan 
berdasarkan UU No.19 Tahun 1968 menjadi Bank Bumi Daya.

Bank Pembangunan Indonesia (BAPINDO)

BAPINDO didirikan dengan UU No.21 tahun 1960 yang merupakan kelanjutan dari Bank Industri Negara (BIN) tahun 1951

Bank Pembangunan Daerah (BPD)

Bank ini didirikan di daerah-daerah tingkat 1. Dasar hukum pendirinya adalah UU No. 13 Tahun 1962

Bank Tabungan Negara (BTN)

BTN berasal dari De Post Paar Bank yang kemudian menjadi Bank Tabungan Pos tahun 1950. Selanjutnya menjadi Bank Negara Indonesia V dan terakhir menjadi Bank Tabungan Negara dengan UU No. 20 Tahun 1968

\section{Bank Mandiri}

Bank ini merupakan hasil merger antara Bank Bumi Daya (BBD), bank Dagang Negara (BDN), Bank Pembangunan Indonesia (BAPINDO) dan Bank Ekspor Impor (Bank Eksim). Hasil merger keempat bank ini dilaksanakan pada tahun 1999.

Dalam praktik perbankan di Indonesia saat ini terdapat beberapa jenis perbankan yang di atur dalam UndangUndang perbankan. Jika kita melihat jenis perbankan sebelum keluar UndangUndang Perbankan Nomor 10 tahun 1998 dengan sebelumnya, yaitu Undang-Undang Nomor 14 Tahun 1967, maka terdapat beberapa perbedaan. Namun, kegiatan utama atau pokok Bank sebagai lembaga keuangan yang menghimpun dana dari masyarakat dan menyalurkan dana tidak berbeda satu sama lain.

Perbedaan jenis perbankan dapat di lihat dari segi fungsi Bank, serta kepemilikan Bank.Dari segi fungsi perbedaan yang terjadi terletak pada luasnya kegiatan atau jumlah produk yang dapat di tawarkan maupun jangkauan wilayah operasinya.Sedangkan kepemilikan perusahaan dilihat dari segi pemilikan saham yang ada serta akte pendirianya.
Perbedaan lain adalah dilihat dari segi siapa nasabah yang mereka layani apakah masyarakat luas atau masyarakat dalam lokasi tertentu (kecamatan). Jenis perbankan juga dibagi ke dalam caranya menentukan harga jual dan harga beli.

Adapun jenis perbankan dewasa ini dapat di tinjau dari berbagai segi antara lain :

Dilihat dari segi fungsinya

Menurut Undang-Undang pokok perbankan Nomor 14 Tahun 1967 jenis perbankan menurut fungsinya terdiri dari :

Bank Umum

Bank Pembangunan

Bank Tabungan

Bank Pasar

Bank Desa

Lubung Desa

Bank Pegawai

Dan bank lainya

Namun setelah keluar UU pokokPerbankan Nomor 7 Tahun 1992 dan ditegaskan lagi dengan keluarnya Undang-Undang RI Nomor 10 Tahun 1998 maka jenis perbankan terdiri atas :

\section{Bank Umum}

Bank Perkreditan Rakyat (BPR)

Di mana Bank Pembangunan dan Bank Tabungan berubah fungsinya menjadi Bank Umum sedangkan Bank Desa,Bank Pasar,Lubung Desa dan Bank Pegawai mejadi Bank Perkreditan Rakyat (BPR) .

Adapun pengertian Bank Umum dan Bank Perkreditan Rakyat sesuai dengan Undang-Undang Nomor 10 Tahun 1998 adalah sebagai berikut.

Bank Umum

Bank umum adalah bank yang melaksanakan kegiatan usaha secara konvensional dan/atau berdasarkan prinsip syariah yang dalam kegiatanya memberikan jasa dalam lalu lintas pembayaran.Sifat jasa yang diberikan adalah umum, dalam arti dapat memberikan seluruh jasa perbankan yang ada.Begitu pula dengan wilaya operasinya dapat dilakukan di seluruh wilayah.Bank umum sering di sebut bank komersil (commercial bank). 
Bank Perkreditan Rakyat (BPR)

Bank Perkreditan Rakyat (BPR) adalah bank yang melaksanakan kegiatan usaha secara konvensional atau berdasarkan prinsip syariah yang dalam kegiatanya tidak memberikan jasa dalam lalu lintas pembayaran.Artinya disini kegiatan BPR jauh lebih sempit jika dibandingkan dengan kegiatan bank umum.

Dilihat dari segi Kepemilikan

Ditinjau dari segi kepemilikan maksudnya adalah siapa saja yang memiliki bank tersebut.Kepemilikan ini dilihat dari akte pendirian dan penguasaan saham yang dimiliki bank yang bersangkutan.

Jenis bank dilihat dari segi kepemilikan tersebut adalah sebagai berikut.

Bank pemilik pemerintah

Di mana baik akte pendirian maupun modalnya dimiliki oleh pemerintah sehingga seluruh keuntungan bank ini dimiliki oleh pemerintah pula.

Contoh bank milik pemerintah antara lain :

Bank Negara Indonesia 46 (BNI)

Bank Rakyat Indonesia (BRI)

Bank Tabungan Negara (BTN)

Sedangkan bank milik pemerintah daerah (pemda) terdapat di daerah tingkat I dan tingkat II masing-masing provinsi. Sebagai contoh:

BPD DKI Jakarta

BPD Jawa Barat

BPD Jawa Tengah

BPD Jawa Timur

BPD Sumatera Utara

BPD Sumatera Selatan

BPD Sulawesi Seltan

Dan BPD lainya.

Bank milik swasta nasional

Bank jenis ini seluruh atau sebagian besarnya dimiliki oleh swasta nasional serta akte pendirianya pun didirikan oleh swasta, begitu pula pembagian keuntunganya untuk keuntungan swasta pula.

Contoh bank milik swasta nasional antara lain :

Bank Muamalat

Bank Central Asia

Bank Bumi Putra
Bank Danamon

Bank Duta

Bank Lippo

Bank Nusa Internasional

Bank Niaga

Bank Universal

Bank Internasional Indonesia.

Bank milik koperasi

Kepemilikan saham-saham bank ini di miliki oleh perusahaan yang berbadan hukum koperasi. Sebagai contoh adalah

Bank Umum Koperasi Indonesia

Bank milik asing

Bank jenis ini merupakan cabang dari bank yang ada di luar negeri, baik milik swasta asing ataupun pemerintah asing.Jelas kepemilikanya pun dimiliki oleh pihak luar negeri.

Contoh bank asing antara lain:

ABN AMRO bank

Deutsche Bank

American Expres Bank

Bank of America

Bank of Tokyo

Bangko Bank

City Bank

European Asian Bank

Hongkong Bank

Standart Chartered Bank

Chase Manhattan Bank

Bank milik campuran

Kepemilikan saham bank campuran dimiliki oleh pihak asing dan pihak swasta nasional. Kepemilikan sahamnya secara mayoritas dipegang oleh warga negara Indonesia.Contoh bank campuran antara lain:

Sumitomo Niaga Bank

Bank Mericorp

Bank Sakura Swadarma

Bank Finconesia

Mitsubishi Buana Bank

Inter Pasifik Bank

Paribas BBD Indonesia

Ing Bank

Sanwa Indonesia Bank

Bank PDFCI ${ }^{12}$

\section{TRANSAKSI PERBANKAN}

${ }^{12}$ Ibid halaman 27-35 
Adapun kegiatan-kegiatan perbankan yang ada di Indonesia dewasa ini adalah sebagai berikut:

\section{Kegiatan-kegiatan bank umum}

Menghimpun dana dari masyarakat (funding) dalam bentuk:

Simpanan Giro (Demand Deposit)

Simpanan Tabungan (Saving Deposit)

Simpanan Deposito (Time Deposit)

Menyalurkan dana ke masyarakat

(Lending) dalam bentuk :

Kredit Investasi

Kredit Modal Kerja

Kredit Perdagangan

Memberika jasa-jasa bank lainnya

(services)seperti :

Transfer (Kirim Uang)

Inkaso (Collection)

Kliring (Clearing)

Save Deposit Box

Bank Card

Bank Notes (Valas)

Bank Garansi

Refrensi Bank

Bank Daft

Letter of Credit $(L / C)$

Cek Wisata (Travellers Cheque)

Jual beli surat-surat berharga

Menerima setoran-setoran seperti :

Pembayaran pajak

Pembayaran air

Pembayaran telepon

Pembayaran listrik

Pembayaran kuliah

Melayani pembayaran-pembayaran seperti:

Gaji/Pensiun/honorarium

Pembayaran deviden

Pembayaran kupon

Pembayaran bonus/hadiah

Di dalam model perbankan dapat member atau menjadi:

Penjamin emisi (underwriter)

Penjamin (guarantor)

Wali amanat (trustee)

Perantara perdagangan efek

(pialang/broker)

Pedagang efek (dealer)

Perusahaan pengelola dana (investment company) $)^{13}$

${ }^{13}$ Ibid halaman $38-40$

\section{REGULASI PERBANKAN BAIK OJK, BI DAN LPS}

OJK melaksanakan tugas pengaturan dan pengawasan terhadap :

Kegiatan jasa keuangan di sektor perbankan

Kegiatan jasa keuangan di sektor pasar modal

Kegiatan jasa keuangan pada sektor peransuransian, dana pension, lembaga pembiayaan, dan lembaga jasa keuangan lainya.

Untuk melaksanakan tugas pengaturan,OJK mempunyai wewenang

Menetapkan peraturan pelaksanaan UU

Menetapkan peraturan perundangundangan di sektor jasa keuangan

Menetapkan peraturan dan keputusan OJK

Menetapkan peraturan mengenai pengawasan di sektor jasa keuangan

Menetapkan kebijakan mengenai pelaksanaan tugas OJK

Menetapkan peraturan mengenai tata cara penetapan perintah tertulis terhadap lembaga jasa keuangan (LJK) dan pihak tertentu

Menetapkan peraturan mengenai tata cara penetapan pengelola statute LJK

Menetapkan struktur organisasi dan infrastruktur,serta

mengelola,memeihara, dan menatausahakan kekayaan dan kewajiban

Menetapkan peraturan mengenai tata cara pengenaan sanksi sesuai dengan ketentuan peraturan perundangundangan di sektor jasa keuangan

Untuk melaksanakan tugas pengawasan,OJK berwenang untuk :

Menetapkan kebijakan operasional pengawasan terhadap kegiatan jasa keuangan

Mengawasi pelaksanaan tugas pengawasan yang dilaksanakankepada eksekutif

Melakukan pengawasan, pemeriksaan, penyelidikan, perlindungan konsumen dan tindakan lain terhadap LJK, pelaku dan atau penunjang kegiatan jasa keuangan 
Memberikan perintah tertulis kepada LJK dan atau pihak tertentu

Melakukan penunjukan atas pengelola statuter

Menetapkan penggunaan pengelola statuter

Menetapkan sanksi administratif terhadap pihak yang melakukan pelanggaran terhadap peraturan perundang-undangan di sektor jasa keuangan

Memberikan atau mencabut: (a) izin usaha; (b) izin perorangan; (c) efektifnya pernyataan pendaftaran; (d) surat tanda terdaftar (STTT); (e) persetujuan untuk melakukan kegiatan usaha; (f) pengesahan; (g) persetujuan atas penetapan pembubaran, dan (h) penetapan lain sesuai peraturan perundang-undangan di sektor jasa keuangan.

\section{AKUNTANBILITAS JASA KEUANGAN}

OTORITAS

Pengaturan tentang akuntabilitas OJK diatur dalam Bab IX UU OJK, yang secara ringkas di sajikan pada tabel berikut ini :

Tabel 17.1 Akuntabilitas Otoritas Jasa Keuangan

\begin{tabular}{|l|l|l|}
\hline No & $\begin{array}{l}\text { Jenis } \\
\text { Kegiatan }\end{array}$ & Kewajiban OJK \\
\hline 1 & $\begin{array}{l}\text { Terkait } \\
\text { Rencana } \\
\text { Kerja dan } \\
\text { Anggaran }\end{array}$ & $\begin{array}{l}\text { Menyusun rencana } \\
\text { kerja dan anggaran } \\
\text { Anggaran diajukan } \\
\text { ke DPR untuk } \\
\text { mendapatkan } \\
\text { persetujuan. }\end{array}$ \\
\hline 2 & $\begin{array}{l}\text { Terkait } \\
\text { Pelaporan }\end{array}$ & $\begin{array}{l}\text { Menyusun laporan } \\
\text { keuangan dan } \\
\text { laporan kegiatan } \\
\text { Menyampaikan } \\
\text { laporan-laporan } \\
\text { kepada Presiden } \\
\text { dan DPR }\end{array}$ \\
\hline 3 & $\begin{array}{l}\text { Terkait } \\
\text { Transparansi }\end{array}$ & $\begin{array}{l}\text { Laporan keuangan } \\
\text { OJK diaudit atau } \\
\text { KAP } \\
\text { ditunjukkan BPK } \\
\text { OJK } \\
\text { mengumumkan }\end{array}$ \\
\hline
\end{tabular}

\begin{tabular}{|l|l|l|}
\hline & $\begin{array}{l}\text { laporan tahunan } \\
\text { OJK kepada publik } \\
\text { melalui r media } \\
\text { cetak ran dan } \\
\text { elektronik }^{14}\end{array}$ \\
\hline
\end{tabular}

Sumber: Laporan Sosialisasi OJK oleh Kementerian Keuangan RI, 2013

Secara umum, peranan bank sentral sangat penting dan strategis dalam upaya menciptakan sistem perbankan yang sehat dan efisien. Perlu diwujudkanya sistem perbankan yang sehat dan efisien itu, karena dunia perbankan adalah salah satu pilar utama dalam pembangunan ekonomi suatu negara.adapun secara khusus, Bank sentral mempunyai peranan yang penting dalam mencegah timbulnya risiko-risiko kerugian yang di derita oleh bank itu sendiri, masyarakat penyimpan dana, dan merugikan serta membahayakan kehidupan perekonomian.

Pada hakikatnya pengaturan dan pengawasan bank dimaksudkan untuk meningkatkan keyakinan dari setiap orang yang mempunyai kepentingan dengan bank,bahwa bank-bank dari segi financial tergolong sehat,bahwa bank dikelola dengan baik dan professional, serta di dalam bank tidak terkandung segi-segi yang merupakan ancaman terhadap kepentingan masyarakat yang menyimpan dananya di bank. ${ }^{15}$

Adapun keempat kewenangan yang diberikan kepada otoritas pengawasan bank tersebut dapat di uraikan sebagai berikut :

Kewenangan memberikan izin (power to licenese)

Melalui kewenangan ini memungkinkan ditetapkan ketentuan dan persyaratan pendirian sebuah bank oleh otoritas pengawas. Kewenangan pemberian izin ini merupakan seleksi paling awal terhadap kehadiran sebuah bank dengan

\footnotetext{
${ }^{14}$ Tri Hendro SP, Conny Tjandra Rahardja. Op.Cit halaman 490-492

${ }^{15}$ Hermansjah.Hukum Perbankan Nasional dan Indonesia.Kencana Prenada Media Group.Jakarta. 2013. Halaman 173
} 
menetapkan tata cara perizinan dan pendirian suatu bank. Pada umumnya persyaratan pendirian bank menyangkut tiga aspek, yaitu: (a) akhlak dan moral calon pemilik Dan pengurus bank,(b) kemampuan menyediakan dana dalam jumlah tertentu untuk modal bank, dan (c) kesungguhan dan kemampuan dari para calon pemilik dan pengurus bank dalam melakukan kegiatan usaha bank. Kewenangan dalam pemberian izin tertentu juga memungkinkan otoritas pengawas bank mencegah terjadinya pendirian bank yang tidak didukung dengan modal yang cukup,yang kurang dipersiapkan dengan baik atau yang dapat digunakan untuk kepentingan pribadi pemilik atau pengurus tanpa mengindahkan kepentingan masyarakat. Kewenangan untuk mengatur (power to regulate)

Kewenangan untuk mengatur ini memungkinkan otoritas pengawas bank untuk menetapkan ketentuan yang menyangkut aspek kegiatan usaha perbankan dalam rangka menciptakan adanya perbankan yang sehat dan mampu memenuhi jasa perbankan sesuai dengan kebutuhan masyarakat. Ketentuan yang dapat di tetapkan antara lain mencangkup pengaturan likuidasi dan solvabilitas bank,jenis usaha yang dapat dilakukan,dan risiko,atau exposure yang dapat diambil oleh bank.

Kewenangan untuk mengendalikan /mengawasi(power to control)

Kewenangan untuk mengendalikan atau mengawasi ini adalah kewenangan yang paling mendasar yang diperlukan oleh otoritas pengawas bank.

Pengawas bank dilaksanakan melalui pengawas tidak langsung (off site supervision) yaitu pengawas yang dilakukan melalui alat pantau seperti laporan berkala yang disampaikan bank ,laporan hasil pemeriksaan, dan informasi lainya. Dengan data yang diperoleh melalui alat pantau, tersebut, otoritas pengawas melakukan penilaian terhadap keadaan usaha dan kesehatan bank.

Selain melalui pengawasan tidak langsung tersebut di atas,otoritas pengawas juga dapat melakukan pengawasan langsung (on site examination) yang dapat berupa pemeriksaan umum dan pemeriksaan khusus.pengawasan langsung ini bertujuan untuk memperoleh gambar tentang ketaatan terhadap peraturan yang berlaku serta untuk mengetahui apakah terdapat praktik-praktikyang tidak sehat yang membahayakan kelangsungan usaha bank.

Kewenangan untuk mengenakan sanksi (power to impose sanction)

Kewenangan yang keempat ini merupakan kewenangan untuk menjatuhkan sanksi apabila sebuah bank kurang atau tidak memenuhi hal-hal yang diatur atau di persyaratkan dalam kewenangan-kewenangan tersebut di atas.pengenaan sanksi ini dimaksudkan agar bank melakukan perbaikan atas kelemahan dan penyimpangan yang dilakukanya.dengan perkataan lain,dalam pengenaan sanksi oleh otoritas pengawas bank tersebut mengandung unsur pembinaan agar suatu bank sungguh-sungguh taat dalam menerapkan peraturan perundangundangan dan prinsip-prinsip perbankan yang sehat. ${ }^{16}$

Berkaitan dengan tugas mengatur dan mengawasi bank, bank Indonesia sebagai bank sentral berwenang :

Menetapkan peraturan perbankan termasuk ketentuan-ketentuan perbankan yang memuat prinsip kehatihatian

Memberikan dan mencabut izin atas kelembagaan dan mencabut izin usaha bank,memberikan izin pembukaan,penutupan dan pemindahan kantor bank,memberikan persetujuan atas kepemilikan dan kepengurusan bank,memberikan izin kepada bank untuk menjalankan kegiatan usaha tertentu.

Melaksanakan pengawasan bank secara langsung dan tidak langsung melalui penyampaian laporan,keterangan oleh bank serta hasil pemeriksaan terhadap

${ }^{16}$ Ibid halaman $175-177$ 
bank,secara berkala ataupun setiap waktu jika diperlukan.

Menugaskan kepada pihak lain untuk dan atas nama bank Indonesia dalam melaksanakan pemeriksaan. Pihak lain yang melaksanakanya pemeriksaan wajib merahasiakan keterangan dan data yang diperoleh.

Memerintahkan bank untuk menghentikan sementara sebagian atau seluruh kegiatan transaksi tertentu apabila menurut penilaian Bank Indonesia terhadap suatu transaksi patut diduga merupakan tindakan pidana di bidang perbankan

Melakukan tindakan tertentu sebagai akibat dari penilaian Bank Indonesia terhadap suatu bank atas kegiatan yang dapat membahayakan usaha bank tersebut dan/atau system perbankan secara keseluruan.

Tugas pengawasan bank akan dilakukan oleh lembaga pengawas sektor jasa keuangan yang independent, dan dibentuk dengan undang-undang.

Mengatur dan mengembangkan system informasi antarbank.sistem informasi dapat dilakukan sendiri oleh Bank Indonesia dan/atau oleh pihak lain dengan persetujuan Bank Indonesia.

Mengenakan sanksi terhadap bank sesuai dengan ketentuan perundangundangan. ${ }^{17}$

Adapun dalam bagian penjelasan dari ketentuan Pasal 29 ayat (5), dikemukakan bahwa pokok-pokok tertentu yang ditetapkan oleh Bank Indonesia memuat antara lain:

Ruang lingkup pembinaan dan pengawasan

Kriteria penawaran tingkat kesehatan

Prinsip kehati-hatian dalam pengelolaan.

Pedoman pemberian informasi kepada nasabah.

Dalam rangka pembinaan dan pengawasan bank tersebut diatas, Pasal 30 Undang-Undang No. 10 tahun 1998 menyatakan bahwa:

Pasal 30 ayat (1) : "Bank wajib menyampaikan kepada Bank Indonesia, segala keterangan dan penjelasan

${ }^{17}$ Ibid halaman $177-178$ usahanya menurut tata cara yang ditetapkan oleh Bank Indonesia."

Pasal 30 ayat (2)

"Bank atas permintaan Bank Indonesia wajib memberikan kesempatan bagi pemeriksaan buku-buku dan berkasberkas yang ada padanya, serta wajib memberikan bantuan yang diperlukan dalam rangka memperoleh kebenaran dari segala keterangan, dokumen, dan penjelasan yang dilaporkan oleh bank yang bersangkutan."

Pasal 30 ayat (30) : "Keterangan tentang bank yang diperoleh berdasarkan ketentuan dimaksud ayat (1) dan ayat (2) tidak di umumkan dan bersifat rahasia." 18

LPS bertugas untuk menjaga kepercayaan masyarakat terhadap lembaga perbankan sesuai dengan fungsi penjamin yang efektif dan kredibel. Prinsip penjamin LPS yang bersifat terbatas mengacuh pada core principle international association of deposite insurers (IADI) ke-9 yang menekan bahwa institusi penjamin simpanan harus mampu mendefinikasikan dengan jelas bentuk simpanan yang akan dijamin (insurable deposit), nilai simpanan yang dijaminkan, dan mampu menjamin mayoritas nasabah yang berada di negaranya.

Peran LPS dalam sistem keuangan di Indonesia diharapkan mampu menhindari efek domino dari instabilitas sistem perbankan (seperti yang pernah terjadi pada tahun 1998 lalu) dengan selalu berupaya menjaga stabilitas sistem perbankan dan keuangan nasional secara keseluruan.Berbagai regulasi diterbitkan untuk memperkuat perbankan nasional. Status LPS sebagai instusi penjamin simpanan adalah (1) LPS merupakan badan hukum; (2) LPS dalam melaksanakan tugasnya bersifat independen, transparan, dan akuntabel,serta (3) LPS bertanggung jawab kepada presiden. ${ }^{19}$

\footnotetext{
18 Ibid halaman 181-182

${ }^{19}$ Tri Hendro SP,Conny Tjandra Rahardja. Op. Cit. halaman 462-463
} 


\section{KETENTUAN HUKUM MENGENAI TRANSAKSI YANG TIDAK WAJAR}

Transaksi keuangan yang tidak wajar diatur dengan tegas pada UU Nomor 8 Tahun 2010 tentang Pencegahan dan Pemberantasan Tindak Pidana Pencucian Uang dan Keputusan Kepala Pusat Pelaporan Analisis dan Transaksi Keuangan Nomor: 2/4/KEP.PPATK/2003 tentang Pedoman Identifikasi Transaksi Keuangan Mencurigakan bagi Penyedia Jasa Keuangan, yaitu transaksi keuangan yang mencurigakan.

Pada Pasal 1 angka 5 UndangUndang Republik Indonesia Nomor 8 Tahun 2010 tentang Pencegahan dan Pemberantasan Tindak Pidana Pencucian Uang disebutkan bahwa yang dimaksud transaksi keuangan mencurigakan adalah :

Transaksi keuangan yang menyimpang dari profil, karakteristik, atau kebiasaan pola transaksi dari pengguna jasa yang bersangkutan;

Transaksi keuangan oleh Pengguna Jasa yang patut diduga dilakukan dengan tujuan untuk menghindari pelaporan transaksi yang bersangkutan yang wajib dilakukan oleh pihak pelapor sesuai dengan ketentuan Undang-Undang ini;

Transaksi keuangan yang dilakukan atau batal dilakukan dengan menggunakan harta kekayaan yang diduga berasal dari hasil tindak pidana; atau

Transaksi keuangan yang diminta PPATK untuk dilaporkan oleh pihak pelapor karena melibatkan harta kekayaan yang diduga berasal dari hasil tindak pidana.

Selanjutnya dalam Lampiran Surat Keputusan Kepala Pusat Pelaporan Analisis Transaksi Keuangan Nomor: 24/KEP.PPATK2003 tentang Pedoman Identifikasi Transaksi Keuangan Mencurigakan bagi Penyedia Jasa Keuangan istilah "Transaksi Keuangan Mencurigakan" berhubungan dengan istilah "mencurigakan" yang memiliki konotasi bahwa transaksi keuangan tersebut seolah-olah sudah pasti terkait dengan tindak pidana sehingga dapat menimbulkan hambatan dalapm pelaporan Transaksi Keuangan Mencurigakan. Pada dasarnya yang dimaksud dengan istilah "Transaksi Keuangan Mencurigakan" adalah transaksi yang menyimpang dari kebiasaan atau tidak wajar dan tidak selalu terkait dengan tindak pidana tertentu.

Sebagai salah satu upaya untuk mencegah masuknya uang hasil tindak kejahatan ke dalam industri perbankan, Bank Indonesia telah menerbitkan ketentuan terkait dengan pencucian uang sejak tahun 2001 mengenai Penerapan Prinsip Mengenal Nasabah (Know Your Customer Principles). Selanjutnya ketentuan dimaksud disempurnakan pada tahun 2009 dengan mengadopsi rekomendasi dengan standar internasional yang lebih komprehensif untuk mencegah dan memberantas pencucian uang dan/atau pendanaan terorisme yang dikeluarkan oleh Financial Action Task Force (FATF), yang dikenal dengan Rekomendasi $40+$ 9 FATF. Rekomendasi tersebut juga digunakan oleh masyarakat internasional dalam penilaian terhadap kepatuhan suatu negara terhadap pelaksanaan program APU dan PPT. Terdapat penyesuaian terminologi dari sebelumnya menggunakan terminologi "KYC" berubah menjadi terminologi "CDD/Customer Due Dilligence"

Seiring dengan perkembangan produk, aktivitas dan teknologi informasi bank yang semakin kompleks dikhawatirkan dapat meningkatkan peluang bagi pihak-pihak yang tidak bertanggung jawab untuk menggunakan produk/jasa bank dalam membantu tindak kejahatannya, Untuk itu, agar penggunaan bank sebagai sarana pencucian uang dan pendanaan terorisme dapat diminimalisir, diperlukan peranan bank yang lebih besar dari sebelumnya yaitu dengan menerapkan Program APU dan PPT yang optimal dan efektif. Penerapan program APU dan PPT oleh bank tidak saja penting untuk pemberantasan 
pencucian uang, melainkan juga untuk mendukung penerapan prudential banking yang dapat melindungi bank dari berbagai risiko yang mungkin timbul antara lain risiko hukum, risiko reputasi dan risiko operasional.

Selain itu, dalam rangka mewujudkan rezim APU dan PPT yang lebih optimal, Bank Indonesia senantiasa secara aktif dan berkesinambungan melakukan koordinasi dengan instansi terkait antara lain Pusat Pelaporan dan Analisis Transaksi Keuangan (PPATK), Komisi Pemberantasan Korupsi (KPK), Badan Pengawas Pasar Modal dan Lembaga Keuangan (Bapepam LK) dan universitas. ${ }^{20}$

Adapun ketentuan lebih lanjut tentang Prinsip Mengenal Nasabah (Know Your Customer) pada Peraturan Bank Indonesia Nomor 3/10/PBI/2001 pada Pasal 4 ayat 1 yang berbunyi :

"Sebelum melakukan hubungan usaha dengan Nasabah, Bank wajib meminta informasi mengenai:

a. identitas calon Nasabah;

b. maksud dan tujuan hubungan usaha yang akan dilakukan calon Nasabah dengan Bank;

c. informasi lain yang memungkinkan Bank untuk dapat mengetahui profil calon Nasabah; dan

d. identitas pihak lain.

Kata transaksi erat sekali dalam dunia perbankan.Dalam transaksi ada kewajiban dan hak yang harus dipenuhi oleh 2 orang atau lebih yang melakukan kesepakatan. Berdasarkan UndangUndang Nomor 8 Tahun 2010 tentang Pencegahan dan Pemberantasan Tindak Pidana Pencucian Uang: "Transaksi

\footnotetext{
${ }^{20}$ Situs Resmi Bank Indonesia, “Program Anti Pencucian Uang dan Pencegahan Pendanaan Terorisme, http://www.bi.go.id/id/perbankan/prinsipmengenal-nasabah/Contents/Default.aspx, 2015, terakhir kali diakses tanggal 10 Juli 2015
}

adalah seluruh kegiatan yang menimbulkan hak dan/atau kewajiban atau menyebabkan timbulnya hubungan hukum antara dua pihak atau lebih." Transaksi yang dilakukan oleh 2 pihak atau lebih dapat berupa penyetoran, penarikan, penukaran atas sejumlah uang, pentransferan dan lain-lain.Pada zaman sekarang ini, kerap kali ditemukan transaksi keuangan yang dianggap mencurigakan atau tidak wajar.Transaski keuangan yang mencurigakan itu seringkali erat hubungannya dengan kasus korupsi, pencucian uang dan pendanaan teroris.

Transaksi keuangan yang mencurigakan adalah transaksi keuangan yang menyimpang dari profil, karakteristik atau kebiasaan pola transaksi dan pengguna jasa yang patut diduga dilakukan untuk tujuan yang menghindari pelaporan.

Pada tahap placement, pelaku menempatkan uang yang tidak sah ke dalam sistem keuangan resmi, dengan sebelumnya mengkonversi terlebih dahulu uang tersebut guna menyembunyikan asal-usul yang tidak sah. Sebagai contoh, uang yang berasal dari hasil perdagangan narkoba biasanya terdiri atas uang-uang kecil dalam tumpukan besar, lebih berat dari narkobanya, kemudian dikonversi ke dalam denominasi uang yang lebih besar, dan didepositokan ke dalam rekening bank, atau dibelikan instrument-instrumen keuangan lain seperti cheques, money orders, dan lainlain. Pada tahap berikutnya, layering (heavy soaping), pelaku berusaha untuk memutuskan hubungan uang hasil kejahatan itu dari sumbernya dengan cara memindahkan uang tersebut dari satu bank ke bank lain hingga beberapa kali. Dengan cara memecah-mecah jumlahnya, dana tersebut disalurkan melalui pembelian dan penjualan instrumen investasi, atau dikirimkan dari perusahaan fiktif yang satu ke perusahaan fiktif yang lain, atau melalui efek-efek atau alat-alat berat atas nama orang lain. Pada tahap akhir, integration (spin dry), uang hasil pencucian dibawa 
kembali ke dalam bentuk pendapatan bersih bahkan menjadi obyek pajak, serta menggunakan uang tersebut ke dalam properti, barang-barang mewah, atau masuk ke perusahaan-perusahaan besar. $^{21}$

Pusat Pelaporan dan Analisis Transaksi Keuangan (PPATK) adalah suatu lembaga independen yang bertugas untuk menyediakan informasi intelijen dibidang keuangan yang bermanfaat dalam penegakan hukum, mengupayakan terciptanya kerjasama antarinstansi untuk mencegah serta memberantas tindak pidana pencucian uang dan pembiayaan terorisme, serta mendukung terciptanya sistem keuangan yang stabil dan aman,

Dalam perkembangannya, tugas dan wewenang PPATK yang tercantum dalam UU No. 15 Tahun 2002 tentang Tindak Pidana Pencucian Uang telah diubah dengan UU No.25 Tahun 2003, ditambah dengan penataan kembali kelembagaan PPATK Pada UU No. 8 Tahun 2010 tentang Pencegahan dan Pemberantasan Tindak Pidana Pencucian Uang yang disahkan dan diundangkan pada tanggal 22 Oktober 2010.

Untuk mencegah terjadinya tindak pidana pencucian uang, PPATK berwenang untuk meminta dan menerima laporan dari penyedia jasa keuangan (PJK), meminta informasi mengenai perkembangan penyidikan atau penuntutan terhadap tindak pidana pencucian uang yang telah dilaporkan kepada penyidik atau penuntut umum, melakukan audit terhadap penyedia jasa keuangan mengenai kepatuhan kewajiban sesuai dengan ketentuan dalam UU dan terhadap pedoman pelaporan mengenai transaksi keuangan, serta memberikan pengecualian kewajiban pelaporan mengenai transaksi keuangan yang dilakukan secara tunai. Termasuk dalam PJK adalah setiap

\footnotetext{
${ }^{21}$ Tri Hendro SP. Conny Tjandra Rahardja. Bank \& Institusi Keuangan Non Bank di Indonesia. UPP STIM YKPN.

Yogyakarta.2014. halaman 476-477
}

orang yang menyediakan jasa di bidang keuangan atau jasa lainnya yang terkait dengan keuangan. Termasuk tetapi kustodian, wali amanat, lembaga penyimpanan dan penyelesaian, pedagang valuta asing, dana pensiun, perusahaan asuransi, dan kantor pos.

PPATK, yang bertanggung jawab kepada Presiden RI, dalam melaksanakan tugas dan kewenangannya bersifat independen dan bebas dari campur tangan serta pengaruhkekuasaan manapun.Dengan demikian, kepala dan wakil kepala PPATK wajib menolak setiap campur tangan dari siapapun dalam pelaksanaan tugas dan kewenangannya. Selain itu, PPATK diperbolehkan untuk melakukan kerja sama dengan pihak terkait, baik nasional maupun internasional dalam melakukan pencegahan dan pemberantasan tindak pidana pencucian uang. ${ }^{22}$

\section{PELANGGARAN DAN SANKSI DARI PENGATURAN TRANSAKSI KEUANGAN YANG TIDAK WAJAR}

Pelaku atau siapapun yang sengaja menempatkan, mentransfer, mengalihkan, membelanjakan, membayar, menghibahkan, menitipkan, membaa ke luar negeri, mengubah bentuk, menukarkan dengan mata uang atau surat berharga atau perbuatan yang lain atas harta kekayaan yang diketahuinya atau patut diduganya merupakan hasil tindak pidana dengan tujuan menyembunyikan atau menyamarkan asal usul harta kekayaan diancam dengan pidana penjara maksimal 20 tahun dengan denda maksimal Rp.10 miliar (Pasal 3 UU No.8 Tahun 2010). Bagi pelaku atau siapapun yang dengan sengaja menyembuyikan atau menyamarkan asal usul, sumber, lokasi, peruntukan, pengalihan hak-hak, atau kepemilikan yang sebenarnya atas harta kekayaan yang diketahuinya atau patut diduganya

${ }^{22}$ Ibid halaman 480 
merupakan hasil tindak pidana diancam dengan pidana penjara maksimal 20 (dua puluh) tahun dengan denda maksimal Rp.5 miliar (Pasal 4 UU No.8 Tahun 2010). Pelaku atau siapapun yang dengan sengaja menerima atau menguasai penepatan, petransferan, pembayaran, hibah sumbangan, penitipan, penukaran, atau menggunakan harta kekayaan yang diketahui atau patut diduganya merupakan hasil tidak pidana diancam dengan pidana penjara maksimal 5 (lima) tahun dengan denda maksimal Rp.1 miliar (Pasal 5 UU No. 8 Tahun 2010).

Selain perorangan, hukum pidana juga dapat dijatuhkan kepada suatu korporasi apabila tindakan pencucian uang : (1) dilakukan atau diperintahkan oleh personil pengendali korporasi; (2) dilakukan untuk memenuhi maksud dan tujuan korporasi; (3) dilakukan sesuai dengan tugas dan fungsi pelaku atau pemberi perintah, serta (4) dilakukan untuk memberikan manfaat bagi korporasi bersangkutan. Adapun pidana pokok yang dijatuhkan terhadap korporasi adalah denda maksimal Rp.100 milliar. Selain itu, korporasi yang bersalah juga dapat dijatuhi pidana tambahan berupa: (1) pengumuman putusan hakim; (2) pembekuan sebagai atau seluruh kegiatan korporasi; (3) pencabutan izin usaha; (4) pembubaran dan/atau pelanggaran korporasi; (5) perampasan aset korporasi untuk negara,atau (6) pengambilalihan korporasi oleh negara (Pasal 7 UU No. 8 Tahun 2010). ${ }^{23}$

Dengan memperhatikan peran OJK yang sangat vital bagi kestabilan sistem keuangan negara, maka lembaga ini haruslah bersifat independen sehingga mampu membangun koordinasi dengan BI sebagai otoritas moneter. Bersifat independen artinya bebas dari campur tangan pihak lain, yang mempunyai fungsi, tugas, dan wewenang pengaturan, pengawas, pemeriksa, dan penyelidikan. Untuk menjalankan kegiatan, OJK akan didanai oleh Anggaran Pendapatan dan Belanja Negara (APBN) atau iuran (retribusi) yang berasal dari pihak-pihak yang menjalankan bisnisnya di sektor jasajasa keuangan.

Menurut Luddin, dengan terintegrasinya sistem pengawasan keuangan (integrated financial supervision) dibawah OJK, maka ada tiga manfaat besar yang dapat diperoleh melalui kehadiran OJK. Pertama, adanya kemudahan dalam melaksanakan harmonisasi pengaturan keuangan negara sehingga tidak terjadi tumpang tindih (overlap) pengawasan dan pengaturan oleh otoritas yang sama. Kedua, proses pengawasan dan pengaturan lembaga keuangan tidak lagi terbentuk kepada hambatan-hambatan yang bersifat institusional.Ketiga, para pemangku kepentingan dapat mengakses secara komprehensif pada data atau informasi lembaga keuangan karena data atau informasi tersebut telah diolah secara terpadu dan transparan sehingga mengurangi asymmetric information. ${ }^{24}$

Tugas pengaturan dan pengawasan bank yang dilakukan BI telah berakhir.Tahun 2014 tugas ini diambil alih oleh Otoritas Jasa Keuangan (OJK).Tugas pengaturan dan pengawasan bank meliputi pemberian dan pencabutan izin atas kelembagaan dan kegiatan usaha tertentu bank, penetapan peraturanperaturan, pelaksanaan pengawasan bank, dan pengenaan sanksi terhadap bank yang melanggar.

Namun demikian, PJK tidak perlu melakukan kegiatan investigasi sebagaimana yang biasa dilakukan oleh penyidik.Sehubungan dengan hal tersebut di atas, tanpa mengabaikan ketentuanPrinsip Mengenal Nasabah yang dikeluarkan oleh masingmasingotoritas pengawas PJK, dalam menerapkan Prinsip Mengenal Nasabah(Know Your Customer) PJK perlu memperhatikan hal-hal sebagai berikut: 
a. Membangun database nasabah yang lengkap dan terkini (up to date) yang mencakup semua informasi penting yang berkaitan dengan nasabah termasuk profil nasabah. Terkait dengan hal ini, PJK perlu membuat profil nasabah yang telah ada dan membuat profil awal bagi nasabah baru.Profil nasabah sangat membantu PJK untuk mengetahui secara cepat adanya indikator (red flag) Transaksi Keuangan Mencurigakan.

b. Memberikan pelatihan yang cukup dan berkesinambungan kepada setiap karyawannya agar memiliki pengetahuan dan ketrampilan yang diperlukan.

c. Membuat kebijakan dan prosedur pemeriksaan secara mendalam dan seksama (enhanced due dilligence) terhadap nasabah yang tergolong/terkait sebagai high risk customer, high risk business dan high risk countries pada waktu pembukaan rekening

Dalam menjalankan tugas pengawasan bank, OJK menggunakan 2 (dua) pendekatan utama, yaitu:

Pengawasan Berdasarkan Kepatuhan (Compliance Based Supervision), yaitu pemantauan kepatuhan bank terhadap ketentuan-ketentuan yang terkait dengan operasi dan pengelolaan bank di masa lalu dengan tujuan untuk memastikan bahwa bank telah beroperasi dan dikelola secara baik dan benar menurut prinsip-prinsip kehati-hatian. Pengawasan terhadap pemenuhan aspek kepatuhan merupakan bagian yang tidak terpisahkan dari pelaksanaan pengawasan bank berdasarkan risiko.

Pengawasan Berdasarkan Risiko (risk based supervision), yaitu pengawasan bank yang menggunakan strategi dan metodologi berdasarkan risiko yang memungkinkan pengawasan bank untuk dapat mendeteksi resiko yang signifikan secara dini dan mengambil tindakan pengawasan yang sesuai dan tepat waktu.

\section{Penutup}

Berdasarkan pembahasan pada bab-bab sebelumnya, maka dapat diambil kesimpulan sebagai berikut:

Pengaturan mengenai transaksi keuangan yang mencurigakan pada Undang-Undang Nomor 8 Tahun 2010 Pasal 1 ayat 5 dan Surat Keputusan Kepala Pusat Pelaporan Analisis dan Transaksi Keuangan Nomor : 2/4/KEP.PPATK/2003 dimaksudkan untuk mencegah dan mengawasi adanya transaksi yang mencurigakan dimana sumber dananya berasal dari tindak kejahatan, serta dapat dicermati dari data nasabah

Akibat hukum terhadap transaksi keuangan yang tidak wajar berdasarkan Undang-Undang Nomor 8 Tahun 2010 Pasal 3 yang berbunyi:" Setiap orang yang menempatkan, mentransfer, mengalihkan, membelanjakan, membayarkan, menghibahkan, menitipkan, membawa ke luar negeri, mengubah bentuk, menukarkan dengan mata uang atau surat berharga atau perbuatan lain atas Harta Kekayaan yang diketahuinya atau patut diduganya merupakan hasil tindak pidana sebagaimana dimaksud dalam Pasal 2 ayat (1) dengan tujuan menyembunyikan atau menyamarkan asal usul Harta Kekayaan dipidana karena tindak pidana Pencucian Uang dengan pidana penjara paling lama 20 (dua puluh) tahun dan denda paling banyak Rp10.000.000.000,00 (sepuluh miliarrupiah).Dengan adanya sanksi yang mengatur dari transaksi keuangan yang tidak wajar, maka transaksi keuangan lebih dicermati dari ketentuan, penetapan atau pun dari pengguna jasa keuangan itu berdasarkan UndangUndang Nomor 8 Tahun 2010.

\section{E. Daftar Pustaka}

Johnny Ibrahim, Teori \& Metodologi Penelitian Hukum Normatif, Bayumedia Publishing, Malang, Cetakan keenam, 2012

Peter Mahmud Marzuki, Penelitian Hukum,Penerbit Kencana Prenada 
Media Group, Jakarta, Cetakan Ketujuh, 2011

Neni Sri Imaniyati, Pengantar Hukum Perbankan Indonesia, Refika Aditama, Bandung, Cetakan Pertama, 2010

Hermansyah, Hukum Perbankan Nasional Indonesia, Kencana Prenada Media Group, Jakarta, Cetakan Ketujuh, 2011

Kasmir, Bank dan Lembaga Keuangan Lainnya, Raja Grafindo Persada, Jakarta, Cetakan Keempat belas, 2012

Tri Hendro SP, Conny Tjandra Rahardja, Bank \& Institusi Keuangan Non Bank di Indonesia, UPP STIM YKPN, Yogyakarta, Cetakan Pertama, 2014

Peraturan Perundang-undangan :

Undang-Undang Dasar 1945

Undang-Undang Nomor 8 Tahun 2010 tentang Pencegahan dan Pemberantasan Tindak Pidana Pencucian Uang

Undang-Undang Nomor 21 Tahun 2011 tentang Otoritas Jasa Keuangan

Undang-Undang Nomor 6 Tahun 2009 tentang Penetapan Peraturan Pemerintah Pengganti Undang-Undang Nomor 2 Tahun 2008 tentang Perubahan Kedua atas Undang-Undang Nomor 23 Tahun 1999 tentang Bank Indonesia menjadi Undang-Undan
Undang-Undang Nomor 7 Tahun 2009 tentang Penetapan Peraturan Pemerintah Pengganti Undang-Undang Nomor 3 TAhun 2008 tentang Perubahan Atas Undang-Undang Nomor 24 Tahun 2004 tentang Lembaga Penjamin Simpanan Undang-Undang Nomor 10 Tahun 1998 tentang Perubahan Atas UndangUndang Nomor 7 Tahun 1992 tentang Perbankan

Peraturan Bank Indonesia Nomor 2/10/PBI/2001 tentang Penerapa Prinsip Mengenal Nasabah (Know Your Customer Principles)

Surat Keputusan Kepala Pusat Analisis dan Transaksi Keuangan Nomor: 2/2KEP.PPATK/2003 tentang Pedoman Identifikasi Transaksi Keuangan Mencurigakan Bagi Penyedia Jasa Keuangan Internet:

Situs Resmi Bank Indonesia, "Program Anti Pencucian Uang dan Pencegahan Pendanaan Terorisme, http://www.bi.go.id/id/perbankan/prinsi p-mengenalnasabah/Contents/Default.aspx, 2015, terakhir kali diakses tanggal 10 Juli 2015 